\title{
DESAIN RENOVASI MASJID AL-MUHAJIRIN PURI HARMONI I CILEUNGSI KABUPATEN BOGOR DENGAN PENDEKATAN ARSITEKTUR BIOFILIK
}

\author{
Fery Mulya Pratama', Nia Suryani ${ }^{2}$ \\ ${ }^{1}$ Universitas Indraprasta PGRI, Program Studi Arsitektur \\ pratama.ars@gmail.com \\ ${ }^{2}$ Universitas Indraprasta PGRI, Program Studi Arsitektur \\ niasuwardi@gmail.com
}

\begin{tabular}{ll}
\hline Informasi artikel \\
\hline Sejarah & \\
artikel: & \\
Diterima & 23 September 2021 \\
Revisi & 29 September 2021 \\
Dipublikasikan & 30 September 2021
\end{tabular}

\section{Kata kunci:}

Masjid

Ibadah

Biofilik

Pusat berkumpul warga

\begin{abstract}
ABSTRAK
Masjid di lingkungan Puri Harmoni 1 Cileungsi Kabupaten Bogor ini bukan hanya digunakan sebagai tempat ibadah juga digunakan sebagai pusat berkumpulnya warga dengan segala kegiatannya yang positif baik itu pengajian rutin, pusat infaq dan sedekah, serta rapat dan diskusi aktif membicarakan setiap permasalahan yang dikontribusikan untuk kemajuan lingkungan perumahan ini. Masjid ini diharapkan bukan hanya sekedar menjadi tempat ibadah tapi juga menjadi wadah yang sangat positif sehingga dapat berkontribusi besar bagi pembentukan karakter warga apalagi generasi muda di perumahan ini yang seolah mengembalikan fungsi masjid seperti pada zaman Rasulullah dulu namun dengan menyesuaikan perkembangan zaman di masa kini. Pendekatan desain yang digunakan adalah teori biofilik. Dalam pendekatan tersebut terdapat 14 pola desain biofilik yang mengartikulasi hubungan antara alam, manusia dan desain lingkungan binaan. Pola-pola tersebut terbagi atas pola alam di dalam ruang yang terdiri atas 7 pola, pola analogi alam 3 pola, sifat pola ruang 4 pola. Dari ke 14 pola tersebut tidak seluruhnya harus dipakai untuk mencapai tujuan, namun yang diutamakan adalah kualitas ruangnya yang berdampak pada pemulihan psikologis penggunanya. Di sini kami akan mengusulkan beberapa kualitas ruang yang ingin dicapai pada perancangan masjid ini untuk diterjemahkan ke dalam desain.
\end{abstract}

Key word:

Mosque

Worship

Biophilic

Positive place residents

\section{ABSTRACT}

The mosque in Puri Harmoni 1 Cileungsi, Bogor Regency is not only used as a place of worship, it is also used as a gathering center for residents with all its positive activities, be it routine recitations, infaq and alms centers, as well as active meetings and discussions to discuss any issues that contribute to environmental progress. this housing. It is hoped that this mosque will not only be a place of worship but also be a very positive place so that it can contribute greatly to the formation of the character of the residents, especially the younger generation in this housing. The design approach used is the biophilic theory. In this approach there are 14 biophilic design patterns that articulate the relationship between nature, humans and the design of the built environment. These patterns are divided into natural patterns in space which consist of 7 patterns, natural analogy patterns 3 patterns, spatial patterns 4 patterns. Of the 14 patterns, not all of them must be used to achieve the goal, but the priority is the quality of the space which has an impact on the psychological recovery of the user. Here we will propose some spatial qualities to be achieved in the design of this mosque to be translated into design.

\section{PENDAHULUAN}

Masjid hadir sebagai rumah ibadah yang dikenal oleh umat Islam dengan makna yang lebih sakral, yakni sebagai rumah Allah. Rumah Sang Khalik yang menciptakan diri kita, dunia dan semesta ini. Masjid juga bukan hanya dikenal sebagai rumah ibadah tempat kita berdialog dengan Allah, namun juga sebagai tempat berdialog dan pusat kegiatan-kegiatan masyarakat. Bahkan pada masa Nabi dulu, masjid lebih sering digunakan sebagai tempat pelayanan masyarakat dibandingkan sebagai tempat ibadah. Seperti Masjid Nabawi digunakan sebagai tempat Nabi berkonsultasi atau berdialog dengan umat-Nya baik terkait masalah pribadi maupun politik dan pemerintahan. Masjid Nabawi juga 
digunakan sebagai pusat penyampaian informasi publik, karena dulu belum ada media efektif untuk menjangkau umat lebih luas selain masjid.

Masjid juga digunakan sebagai tempat untuk menyalurkan santunan sosial, baik zakat dan sedekah. Masjid juga digunakan sebagai tempat untuk mengontrol semua kondisi dan keadaan umat, karena hampir semua kegiatan masyarakat pada masa itu berpusat di Masjid. Masjid dimaknai sebagai perekat umat dan seluruh lapisan masyarakat

Kata "masjid" berasal dari Bahasa Arab yang berarti membungkuk dengan hormat dalam posisi sujud pada waktu solat, atau diserap kemudian menjadi tempat sujud. Dari pengertian asal bahasa ini maka secara terminologi syar'i. Masjid adalah setiap bangunan atau tempat yang diperuntukkan keberadaannya untuk beribadah kepada Allah dan sujud kepada-Nya ditempat itu walaupun sebenarnya, Islam membolehkan sholat diseluruh bagian bumi, kecuali pada tempat yang sudah jelas-jelas ada najisnya.

M. Quraish Shihab (1996:459) menulis bahwa dalam pengertian sehari-hari, masjid merupakan bangunan tempat sholat kaum muslimin. Tetapi karena akar katanya mengandung makna tunduk dan patuh, hakekat masjid adalah tempat melakukan segala aktivitas yang mengandung kepatuhan kepada Allah semata.

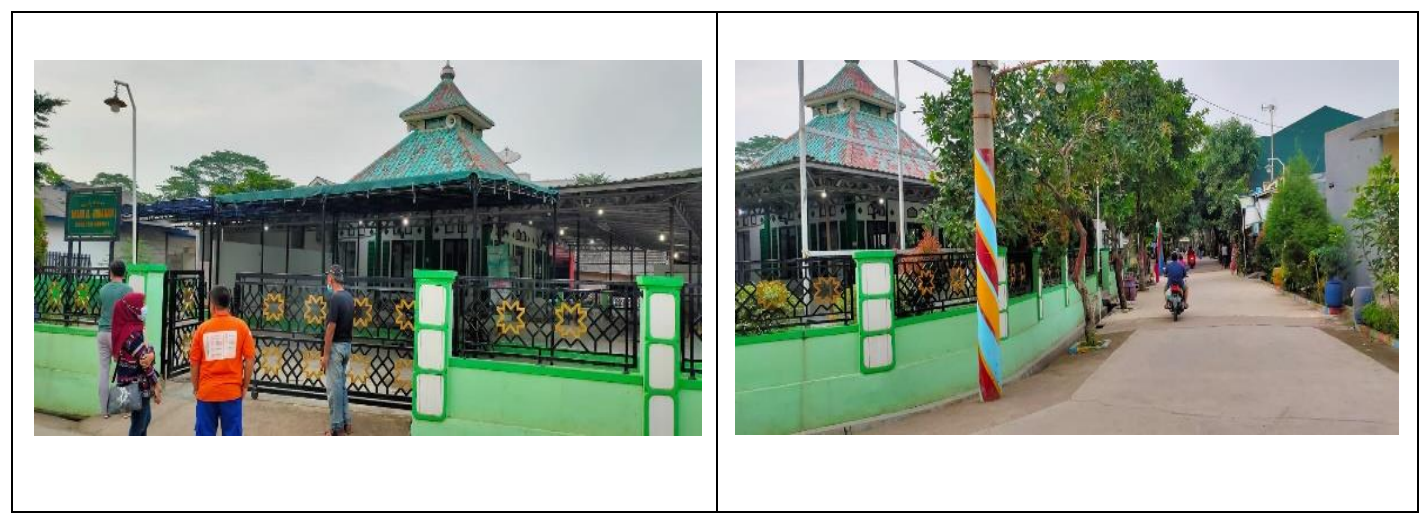

Gambar 1. Kondisi Eksisting Tapak

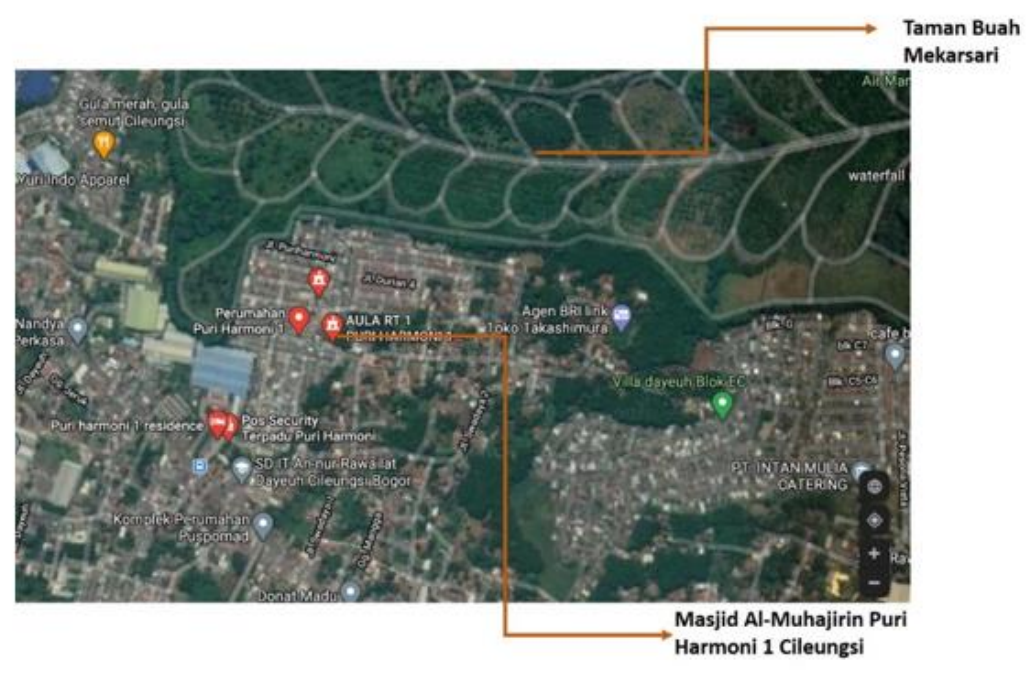

Gambar 2. Lokasi

Melihat kondisi tersebut, sebenarnya terdapat masalah juga keinginan dari seluruh pengguna masjid ini yang diwakili oleh Panitia bahwa baiknya masjid bisa mengakomodasi kapasitas beribadah dari semua warga muslim di Perumahan Puri Harmoni 1 yang bergantung pada keberadaan masjid ini. 
Selain itu mereka berharap masjid bukan hanya sekedar menjadi tempat ibadah tapi juga menjadi wadah yang sangat positif sehingga dapat berkontribusi besar bagi pembentukan karakter warga apalagi generasi muda di perumahan ini yang seolah mengembalikan fungsi masjid seperti pada zaman Rasulullah dulu namun dengan menyesuaikan perkembangan zaman di masa kini. Kami sebagai tim pengabdian masyarakat Universitas Indraprasta PGRI melakukan diskusi dengan Ketua Panitia Pelaksana Renovasi Masjid Al-Muhajirin dan memberanikan diri melakukan pengabdian masyarakat dengan judul PKM Desain Renovasi Masjid Al-Muhajirin Puri Harmoni 1 Cileungsi.

Berdasarkan hasil diskusi intensif dengan mitra diperoleh kesepakatan tujuan perancangan masjid yang baru bukan hanya sekedar menambah jumlah kapasitas jamaah dan menjadi tempat ibadah warga, tapi juga sebagai pusat pemulihan spiritual bagi warga Puri Harmoni 1. Dari persoalan dan kebutuhan mitra, kami berusaha turut andil dalam proses desain masjid sekaligus mengedukasi warga dari sudut pandang pengetahuan arsitektur. Pendekataan perancangan bangunan masjid yang kami terapkan adalah arsitektur biofilik yang selaras dengan nilai sosial yang diusung warga puri harmoni yang agamis, ramah serta toleran terhadap perbedaan. Untuk mencapai tujuan desain Langkah awal dimulai dengan mengurai persoalan desain. kami membagi pembahasan menjadi dua topik. Topik pertama adalah mengurai persoalan spasial dalam beribadah, di dalamnya membahas kegiatan beribadahyang sekarang ada dan harapan dimasa yang akan datang, pola aktifitas, kebutuhan dan besaran ruang, serta orientasi ruangnya. Sedangkan topik kedua adalah kualitas arsitektur biofilik, yaitu bagaimana cara mendapatkan kualitas ruang yang ideal sebagai sarana beribadah sekaligus media yang dapat memicu pemulihan spiritual warganya.

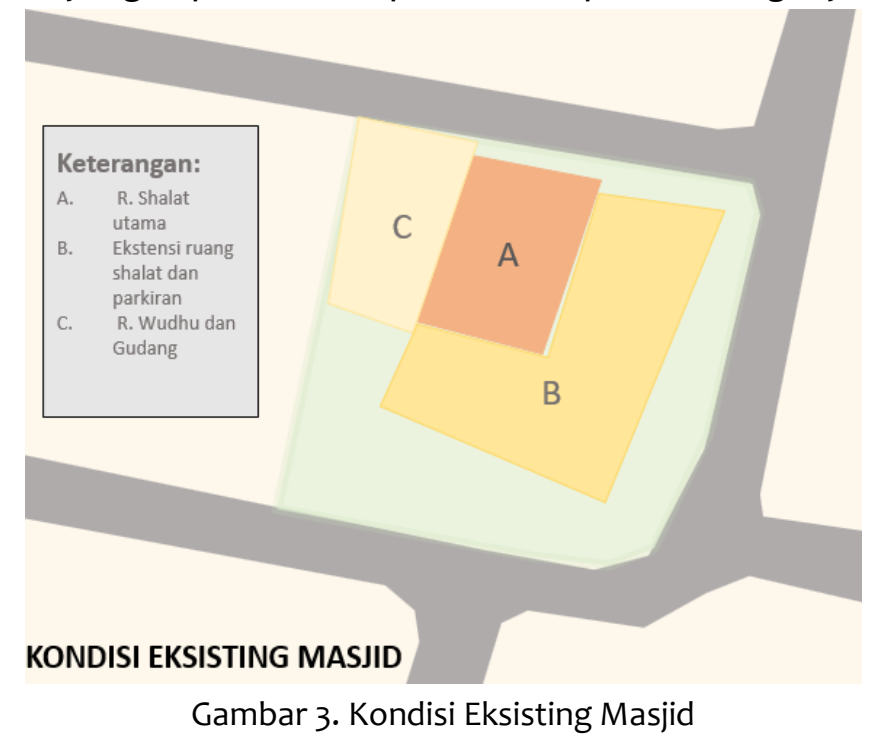

\section{Persoalan Spasial dalam Beribadah}

Kami mulai dengan mememetakan persoalan dengan pengukuran luas lahan dan banguan eksisting, mensingkronkan antara bentuk lahan dengan titik koordinat lahan pada peta serta pengecekan arah kiblat terkini. Langkah ini dijadikan titik tolak pekerjaan desain karena isu utama kegiatan beribadah saat ini adalah adalah arah mihrab yang bergeser beberapa tahun silam akibat gempa bumi dan dianggap mengurangi kesempurnaan dalam beribadah. Seperti informasi yang ditampilkan pada gambar 3. Berdasarkan hasil pemetaan lapangan kondisi eksisting dari Masjid Al Muhajirin, bangunan utama ruang shalat hanya berukuran 10meter x 12 meter, kemudian diperluas dengan kanopi selebar 8 meter yang meliputi teras masjid, parkiran dan ditambahkan bangunan ruang wudhu dan gudang disisi baratnya. Selain kurangnya luasan ruang shalat dan kegiatan penunjang, arah 
kiblat masjid ini belum menyesuaikan pergeseran arah kiblat terkini. Setelah tahap ini dilakukan, kami berusaha membandingkan bentuk dan luasan banguan eksisting dan keinginan panitia pembangunan masjid yang diharapkan menjadi 2ometer $x$ 2ometer dan mengarah ke kiblat terkini. Hasilnya seperti yang terlihat pada gambar 4 dimana luas bangunan yang diharapkan tidak sesuai dengan ketersedian lahan sehingga membutuhkan studi ulang terhadap aktifitas di dalam masjid. kami sebagai tim pengabdi kemudian memetakan aktifitas di dalam lingkungan sekitar dan mencari masalah yang muncul dari proses desain. Berdasarkan hasil penelusuran kondisi tapak persolan pertama yang timbul adalah rencana luasan yang diharapkan jika diarahkan ke kiblat melampaui batas lahan yang tersedia. Berdasarkan temuan tersebut kami melanjutkan dengan menganalisis pola aktifitas bangunan eksisting, hirarki aktifitas ideal dan kebutuhan aktivitas di masa yang akan datang sehingga berdampak pada pola ruang masjid yang baru.
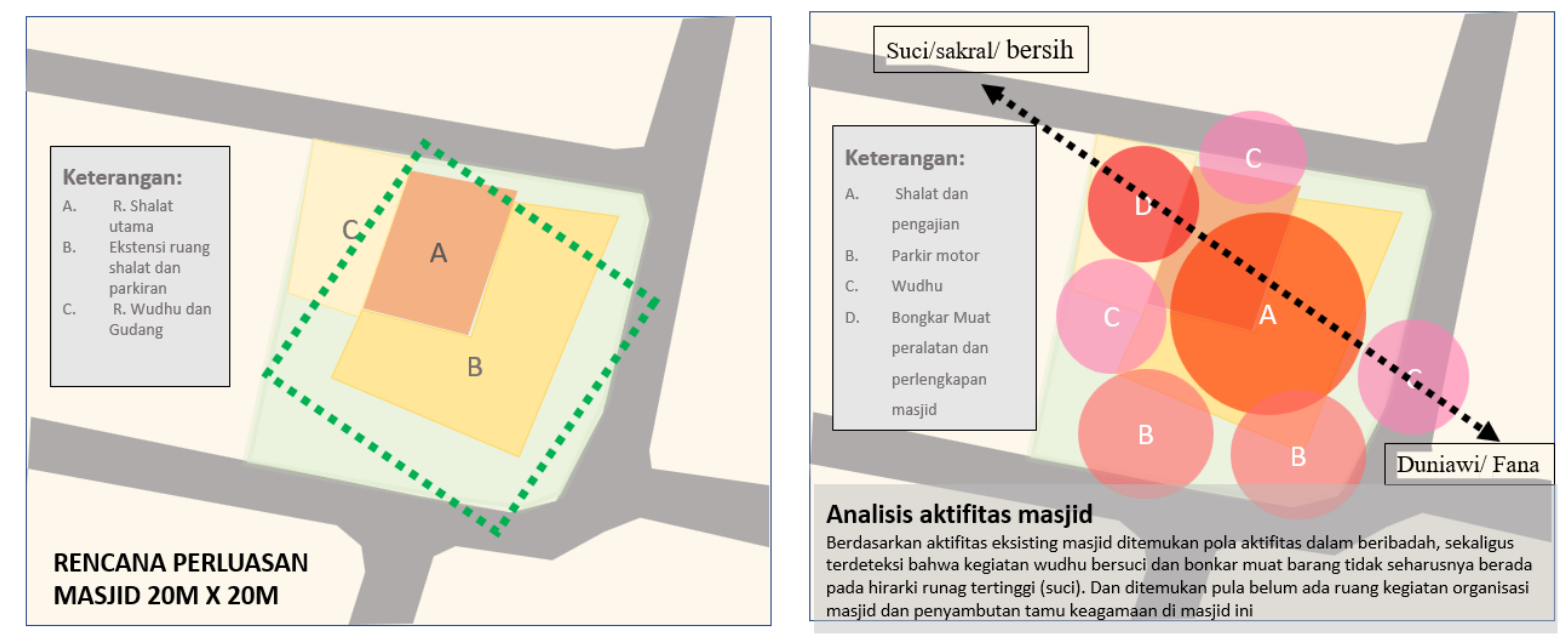

Gambar 4. Analisis Rencana Perluasan Ruang dan Analisis Aktifitas Masjid

Hasil ini kemudian disingkronkan dengan analisis aktifitas lingkungan di luar masjid dan arah akses bukaan masjid eksisting. Pada gambar 5 ditemukan bahwa pada kondisi eksisting arah akses bukaan sudah tepat karena dapat diakses dari segala penjuru, dan penempatan akses utama menuju masjid juga sudah tepat karena berada pada bagian aktifitas lingkungan yang tinggi sekaligus sebagai wajah bangunan yang akan terekspos pertama kali. Berdasarkan temuan ini maka konsep wajah dan arah bukaan akan mempertahankan apa yang telah dicapai oleh bangunan eksisting namun tetap dibuat penyesuaian kualitas ruang untuk mencapai tujuan perancangan.
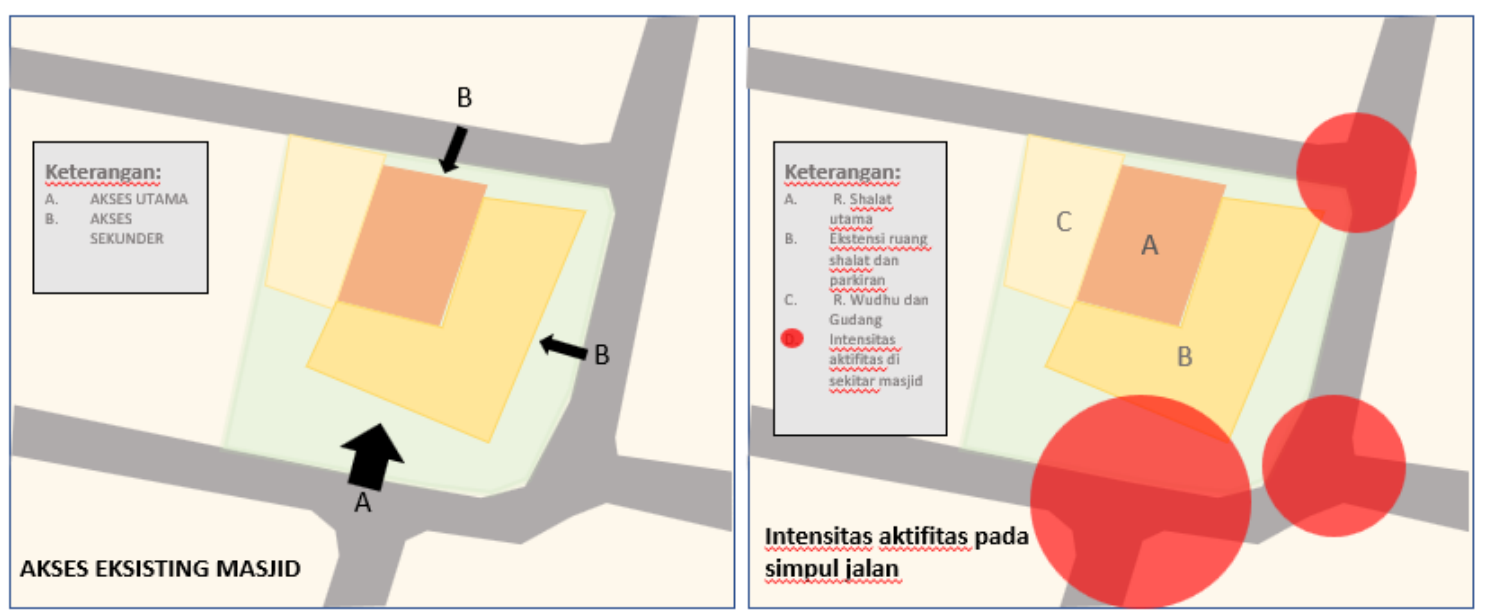

Gambar 5. Analisis Aksesibilitas dan Aktifitas pada Simpul Jalan 
Berdasarkan temuan pada analisis desain di atas, maka seecara lebih detail kami mengusulkan perubahan pola ruang dengan kosep spasial berikut ini.

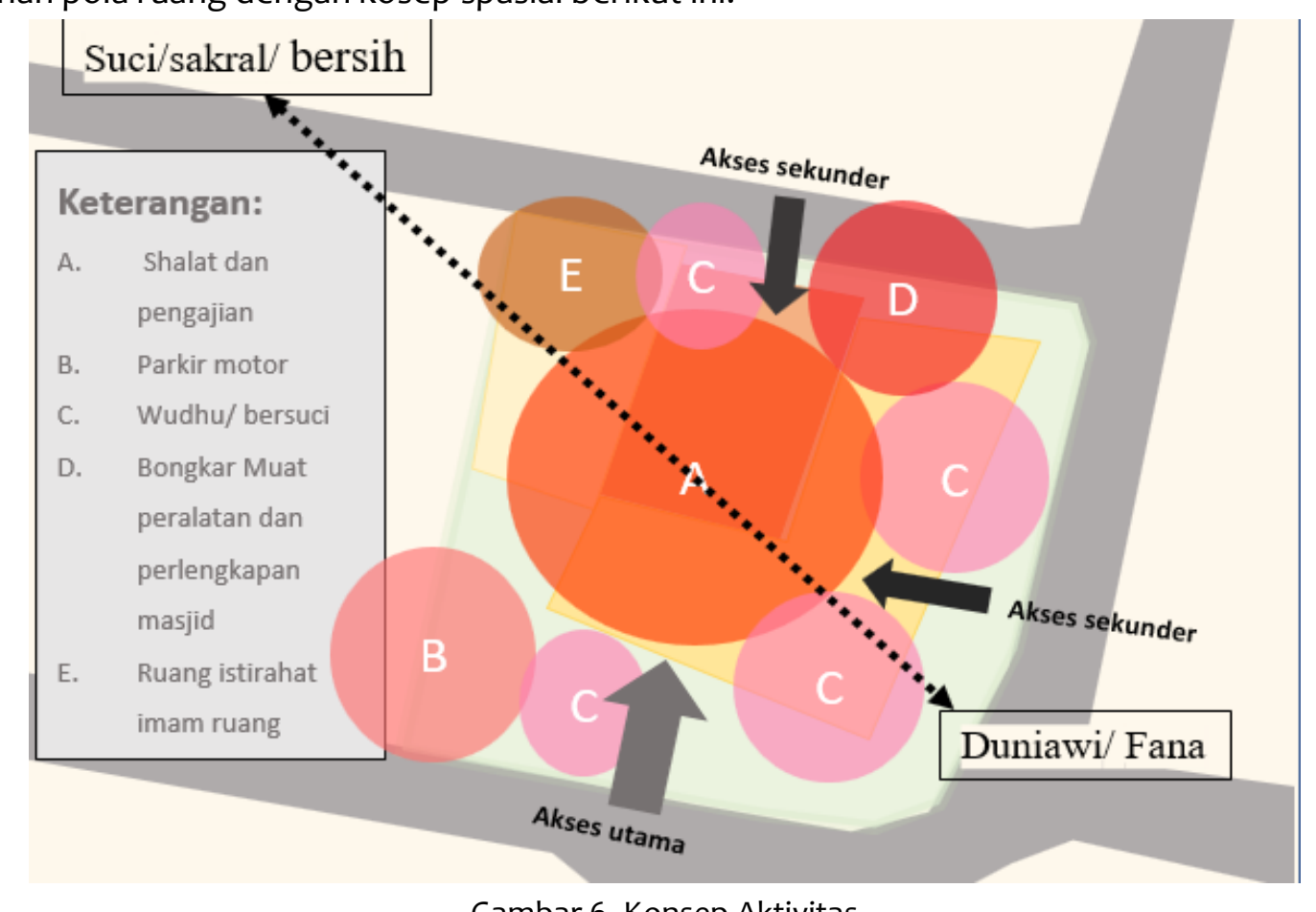

Gambar 6. Konsep Aktivitas

\section{Kualitas Arsitektur Biofilik}

Secara spesifik kami mengusulkan aktifitas di Al Muhajirin sebagai sentra aktivitas beribadah bagi warga Puri Harmoni 1 direncanakan sebagai Menara Air yang di satu sisi menjadi sebagai sarana peribatan yang megah, namun bisa memberi kesan teduh, asri, dan terbuka, sehingga menggundang setiap warga maupun pendatang yang melintas untuk singgah dan shalat di dalam tanpa memandang perbedaan paham serta cara beribadahnya. Untuk mencapai tujuan desain masjid kami mengusung pendekatan arsitektur biofilik. yaitu desain yang secara efektif menghilangkan stres dan kecemasan, meningkatkan kreativitas dan kejernihan pikiran, meningkatkan kesejahteraan dan mempercepat proses penyembuhan. Terdapat 14 pola desain biofilik yang mengartikulasi hubungan antara alam, manusia dan desain lingkungan binaan. Pola-pola tersebut terbagi atas pola alam di dalam ruang yang terdiri atas 7 pola, pola analogi alam 3 pola, sifat pola ruang 4 pola. Dari ke 14 pola tersebut tidak seluruhnya harus dipakai untuk mencapai tujuan, namun yang diutamakan adalah kualitas ruangnya yang berdampak pada pemulihan psikologis penggunanya. Di sini kami akan mengusulkan beberapa kualitas ruang yang ingin dicapai pada perancangan masjid ini untuk diterjemahkan ke dalam desain.

Citra yang telah disepakati kemudian dikembangkan pada tema rancangan bangunan masjid yang berperan sebagai ruang pemulihan hati dan pikiran dari penggunanya. Kualitas ruang yang dimaksud pada tema rancangan ini meliputi, memasukan unsur alam kedalam bangunan, penggunaan material alam, kehadiran elemen air, dan interaksi antara pengguna dengan elemen pembentuk ruangnya. Untuk poin memasukan unsur alam ditunjang potensi lokasi bangunan yang dikelilingi jalan dan berada di beberapa persimpangan lorong jalan. Lokasi tapak seperti ini membuat angin selalu bergerak kesegala arah, menembus ruang hijau, menggerakan dahan dan daun pepohonan rindang, memberikan kesegaran dan kesejukan ke segala penjuru masjid. Potensi jalanyang terbuka memberikan potensi penggunaan cahaya alami sebagai sumber penerangan sekaligus memberikan efek psikologis bagi penggunanya. 
Pengunaan material alam seperti batu alam, kayu, maupun vegetasi juga memberikan peran mendekatakan interaksi panca indera manusia dengan alam yang berdampak menurunnya tingkat stress secara visual maupun pikiran. Hadirnya unsur air juga berperan menstimulus pikiran akan kesan sejuk dan ketenangan pikiran, oleh karena itu bangunan masjid ini didesain dengan adanya kolam pantul berundak sehingga memunculkan efek bunyi gemericik air, sekaligus suasana air yang tenang. Interaksi antar elemen alam pada masjid dan penggunanya memberikan efek puitis pada bangunan sekaligus mencapai tujuan utamanya. Interaksi antar elemen tersebut diaplikasikan pada pagar bangunan digantikan dengan ruang terbuka hijau membukit, dan rimbunnya deretan pohon hijau yang mengelilingi bangunan masjid, memberikan kesan manusiawi, terbuka, ramah. Koridor jalan berundak yang diapit dua buah pohon rindang menjadi penyambut setiap pengguna yang datang. untuk beribadah di dalamnya. Efek refleksi cahaya matahari pada kolam pantul yang tenang di sekeliling masjid, bunyi gemericik air, efek bayangan pepohonan pada bangunan yang terus bergerak dan desiran angin semilir yang menembus pepohonan, diharapkan memberikan ketenangan pikiran bagi penggunanya.

\section{METODOLOGI}

Dalam mengolah desain dan berkomunikasi dengan pengguna kami mencoba menggunakan pendekatan partisipatif dan pengembangan community based development. Widaningsih dan Barliana mengungkapkan pendekatan partisipatif memiliki peluang untuk mengembangkan dan menjamin suatu komunitas sosial yang memungkinkan terjadinya proses belajar dari masyarakat untuk beradaptasi dan berintegrasi dengan lingkungannya. Masyarakat yang akan tinggal di dalam wilayah dunia-hidup baru yang direncanakan dibina sejak awal oleh arsitek dalam hal ini pelaksana abdimas untuk turut serta, urun rembug dalam perancangan desain masjid ini. Posisi metode partisipatif pada kampung-kota bukan sekedar kebutuhan untuk menciptakan 'rasa saling memiliki', tetapi secara eksistensial mampu membangun pengertian bahwa mereka hidup dalam satu duniahidup yang menjadi rumah mereka selama mungkin. Pendekatan partisipatif tidak hanya dilakukan oleh pelaksana abdimas, akan tetapi menggali dan menumbuhkan partisipasi masyarakat dalam keseluruhan proses kegiatan abdimas karena dalam pendekatan partisipatif dalam penelitian arsitektur harus bermuara pada tujuan akhir bahwa hasil abdimas tersebut dapat diimplementasikan dalam kehidupan masyarakat. Sebagai bagian dari proses tersebut, pendekatan partisipatif juga merupakan pengembangan Community based development yang mengisyaratkan pentingnya penerapan hasil penelitian dan pelaksanaan proses pembangunan yang didasarkan pada kebutuhan masyarakat. Pola seperti itu memungkinkan partisipasi masyarakat dapat dikembangkan secara optimal. Partisipasi masyarakat dilakukan dengan tujuan akhir dari pembangunan masyarakat adalah untuk meningkatkan kesejahteraan penduduknya secara langsung dan secara tidak langsung adalah meletakkan dasardasar pembangunan daerah dan pembangunan nasional.

Namun pendekatan desain yang digunakan adalah teori biofilik. Dalam pendekatan tersebut terdapat 14 pola desain biofilik yang mengartikulasi hubungan antara alam, manusia dan desain lingkungan binaan. Pola-pola tersebut terbagi atas pola alam di dalam ruang yang terdiri atas 7 pola, pola analogi alam 3 pola, sifat pola ruang 4 pola. Dari ke 14 pola tersebut tidak seluruhnya harus dipakai untuk mencapai tujuan, namun yang diutamakan adalah kualitas ruangnya yang berdampak pada pemulihan psikologis penggunanya. Di sini kami akan mengusulkan beberapa kualitas ruang yang ingin dicapai pada perancangan masjid ini untuk diterjemahkan ke dalam desain. 


\section{HASIL DAN PEMBAHASAN}

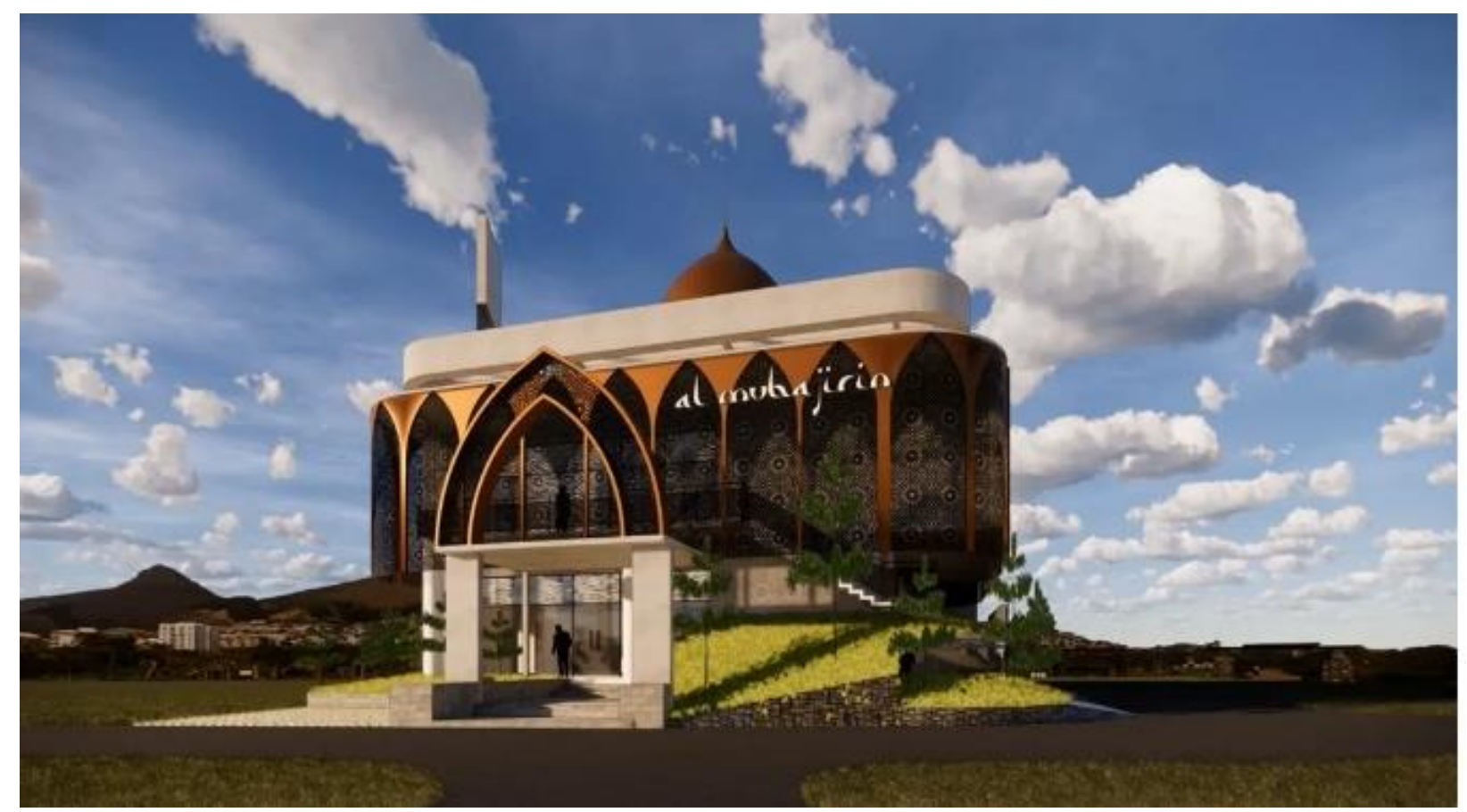

Gambar 7. Desain Masjid

Berdasarkan komunikasi intensif antara tim pengabdi dan pihak mitra pada akhirnya ditemukan titik temu mengenai wujud desain masjid yang akan dihadirkan beserta pembagian ruangnya serta kualitas biofilik yang coba ditampilkan. Untuk tata ruang lahan direncanakan banguan utama berupa ruang untuk shalat adalah 18 meter x 18 meter di lantai dasar, maupun pada ruang diatasnya. Kebutuhan ruang tersebut belum termasuk fungsi penunjang seperti ruang mihrab, ruang $\mathrm{dkm}$, tangga, raung wudhu, menara masjid, parkiran serta dan ruang sarana dan prasarana aktivitas masjid. Orientasi massa bangunan masjid haruslah menghadap kearah kabah yang mana turut membuat pengolahan lahan tidak dapat maksimal. Untuk menyikapi persoalan lahan dan kebutuhan ruang, tim pengabdi mengusulkan ide pengaturan ruang dengan permainan tata letak elevasi ruang sesuai dengan hirarki kebutuhan ruang dan nilai local tata ruang masjidnya. Sebagai pusat aktivitas tentu saja ruang shalat menjadi porosnya. Sebuah ruang persegi berukuran 18 meter $x 18$ meter setinggi 4,5meter setiap lantainya. Blok masa bangunan ditempatkan menghadap utara, lalu diputar sejauh $295^{\circ}$ kearah barat laut. Untuk memberikan kesan megah, posisi lantai bangunan ditinggikan sekitar satu meter dari level jalan. Setelah ditinggikan agar bangunan berkesan ringan dan melayang, batas vertikal lantai dasar dibuat transparan, sehingga tidak terlihat ada bangunan berkesan hanya ada di lantai dua saja. 

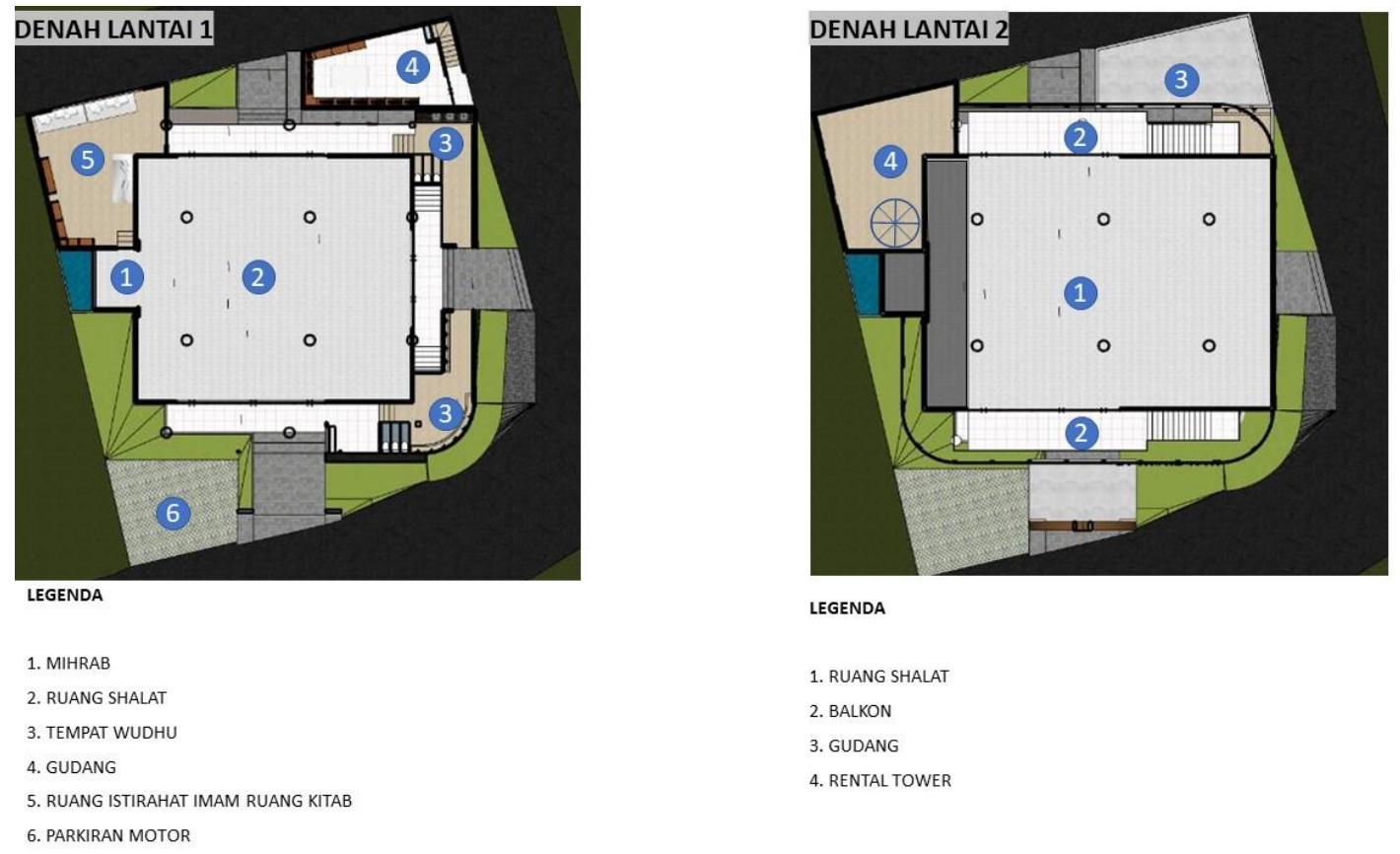

Gambar 8. Denah Masjid Al-Muhajirin

Pada sisi barat laut, di depan ruang shalat terdapat ruang mihrab yang berada tepat di sumbu perpotongan ruang. Terhubung dengan ruang shalat dan mihrab pada sisi barat daya hingga utara terdapat tower masjid, ruang DKM di lantai 1, serta ruang penyedia jaringan internet di lantai dua yang dilengkapi akses menuju atap masjid. Untuk ruang wudhu diletakan di bagian luar bangunan masjid dan berada di setiiap akses masuk kedalam bangunan. Pada sisi tenggara, tempat wudhu dilengkapi dengan toilet terpisah antara pria dan wanita. Dengan kebutuhan ruang yang cukup besar, penataan ruang disiasati dengan meletakan toilet lebih rendah dari lantai bangunan dan memanfaatkan ruang dibawah tangga menuju lantai kedua. Diluar bangunan utama terdapat bangunan servis yang berfungsi sebagai Gudang sarana dan prasarana masjid setinggi 2 lantai dengan akses terpisah.

\section{Kualitas Ruang}

Koneksi visual dengan alam hubungan visual yang terjadi secara alami dan dapat dinikmati secara visual adalah aliran air alami, vegetasi, hewan, serangga dan kontur tanah. Hubungan visual yang terjadi secara buatan atau dibangun berupa aliran air mekanis, kolam ikan, akuarium, dinding hijau, karya seni dengan pemandangan alam, video yang menggambarkan pemandangan alam, lanskap berdesain tinggi. Ruang dengan variabilitas termal dan aliran udara yang baik terasa menyegarkan, aktif, hidup dan nyaman. Ruang memberikan rasa fleksibilitas dan rasa aman. Perubahan halus di udara meliputi suhu, kelembapan, aliran udara dan suhu permukaan yang meniru lingkungan alami. Unsur angin sepoi-sepoi atau gerakan alami lainnya dapat meningkatkan konsentrasi.

Kehadiran air atribut multi sensorik air untuk meningkatkan pengalaman suatu tempat dengan cara yang menenagkan, mendorong, kontemplasi, meningkatkan suasana hati dan memberikan pemulihan dari kelelahan kognitif. Pertimbangan desain untuk mengoptimalkan dampak keberadaan air yaitu prioritaskan pengalaman air multi-indera untuk mencapai hasil maksimal dan menguntungkan dan memrioritaskan pergerakan air yang berfluktasi secara alami daripada yang dapat diprediksi geraknya. Ruang pencahayaan dinamis yang baik dapat menyampaikan ekspresi waktu dan gerakan untuk membangkitkan perasaan tenang. Memanfaatkan berbagai intensitas cahaya dan bayangan yang berubah dari waktu ke waktu untuk menciptakan kondisi yang terjadi di alam. Tujuan dari pola pencahayaan dinamis adalah untuk menyediakan 
pencahayaan yang merangsang mata dan menarik perhatian dengan cara menimbulkan respons psikologis atau fisiologis yang positif.

Ransangan sensorik non-ritmik yang terjadi secara alami adalah gerakan awan, angin, gemerisik tanaman, suara air, gerakan hewan, kicau burung, bunga, pohon dan tumbuhan yang harum. Rangsangan non-ritmik yang terjadi secara sengaja seperti kain atau layer bergelombang, bahan yang bergerak atau berkilau dengan cahaya atau angin, refleksi angin di permukaan, bayangan atau cahaya belang-belang yang berubah dengan gerakan atau waktu, dan aroma terapi. Ruang dengan koneksi yang baik dengan sisitem alam membangkitkan hubungan dengan keseluruhan yang lebih besar, membuat seseorang sadar akan musim dan siklus kehidupan. Tujuan hubungan dengan sistem alam adalah untuk meningkatkan kesadaran akan sifat-sifat alam dan pemeliharaan lingkungan. Pertimbangan desain dan peluang yang dapat membantu menciptakan koneksi berkualitas dengan sistem alam yaitu integrasi penangkapan dan pengolahan air hujan ke dalam lanskap.

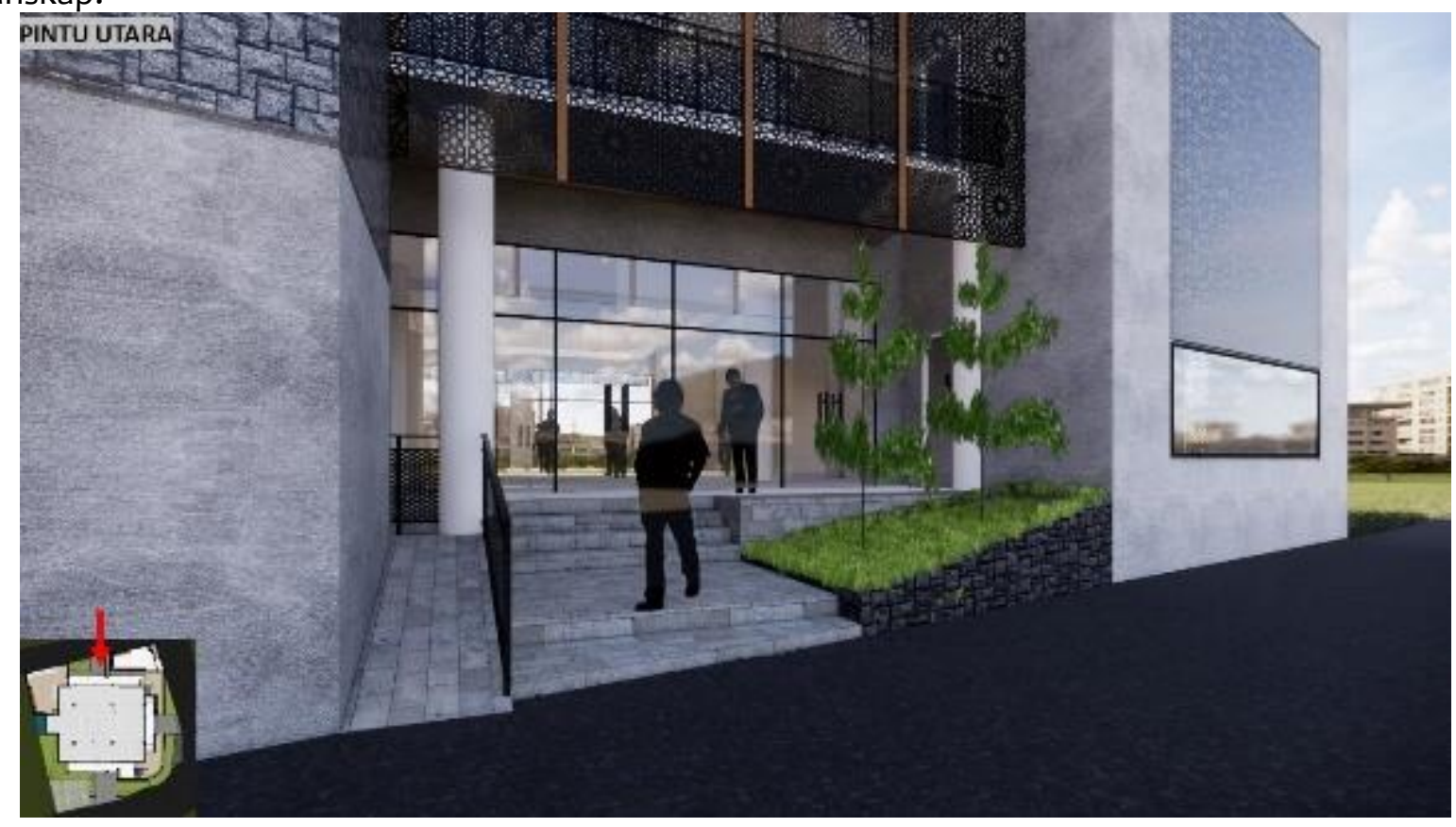

Gambar 9. Akses menuju Masjid yang dilengkapi Ramp

Konsep ramah juga diterapkan pada unsur aksesibiltas bangunan. Dengan mempertimbangkan kemudahan beribadah di usia senja, dan jamaah yang kini harus menggunakan kursi roda, pada sisi timur akses masuk dilengkapi dengan ramp sehingga lebih ramah bagi jamaah yang menggunakan kursi roda. Pada sisi lainnya seluruh akses tetap menggunakan tangga untuk mencapai bangunan masjid. Pada sisi barat daya terdapat akses utama menuju masjidkarena berhadapan langsung dengan jalan yang paling besar dan simpul dari beberapa Lorong jalan. Akses utama ini dilengkapi dengan gerbang masuk parkiran motor dan ruang wudhu. Di sisi tenggara dan timur juga terdapat akses masuk ke dalam masjid. Akses masuk di sisi tenggara memiliki akses langsung menuju toilet dan tangga menuju lantai dua di mana merupakan ruang shalat yang diperuntukan untuk jamaah wanita. 

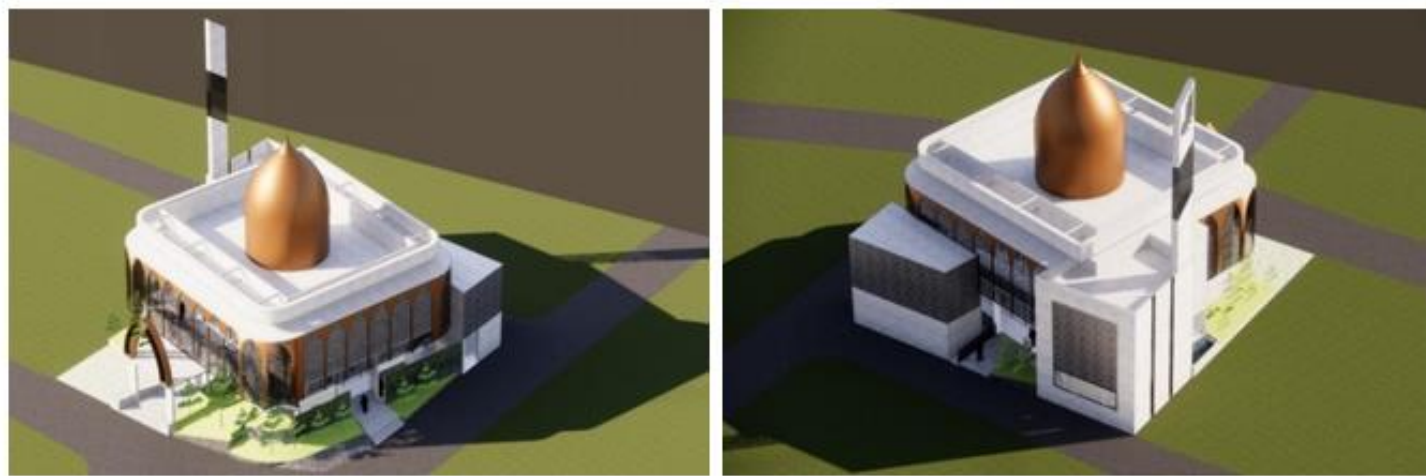

Gambar 10. Gubahan Massa dan Wujud Bangunan

Secara garis besar wujud bangunan dibuat terbuka secara visual dan seolah diangkat dari permukaan tanah, Untuk menghindari radiasi matahari langsung, dinding kaca dan bukaan bangunan dibuat lebih menjorok ke dalam sehingga memberikan ruang bagi teras sebagai area transisi. Pada sisi barat laut hingga barat daya dilengkapi dengan kolam pantul dan pohon rindang sehingga sinar matahari yang tersaring dan terpantul terlebih dulu telah kehilangan panasnya sebelum memasuki bangunan.

Ornamen arsitektur masjid yang umumnya memberi kesan megah namun berat dan rumit, pada bangunan masjid ini dintepretasikan ulang menjadi bentuk yang lebih sederhana dan pemilihan warna yang dapat lebih membaur dengan lingkungan tanpa menghilangkan kesan megahnya. Sebagai aplikasinya pada lantai kedua, teras balkon sebagai area transisi diselimuti dinding ornament islami transparan sebagai tabir matahari yang memberikan pantulan bayangan yang menarik di dalamnya.

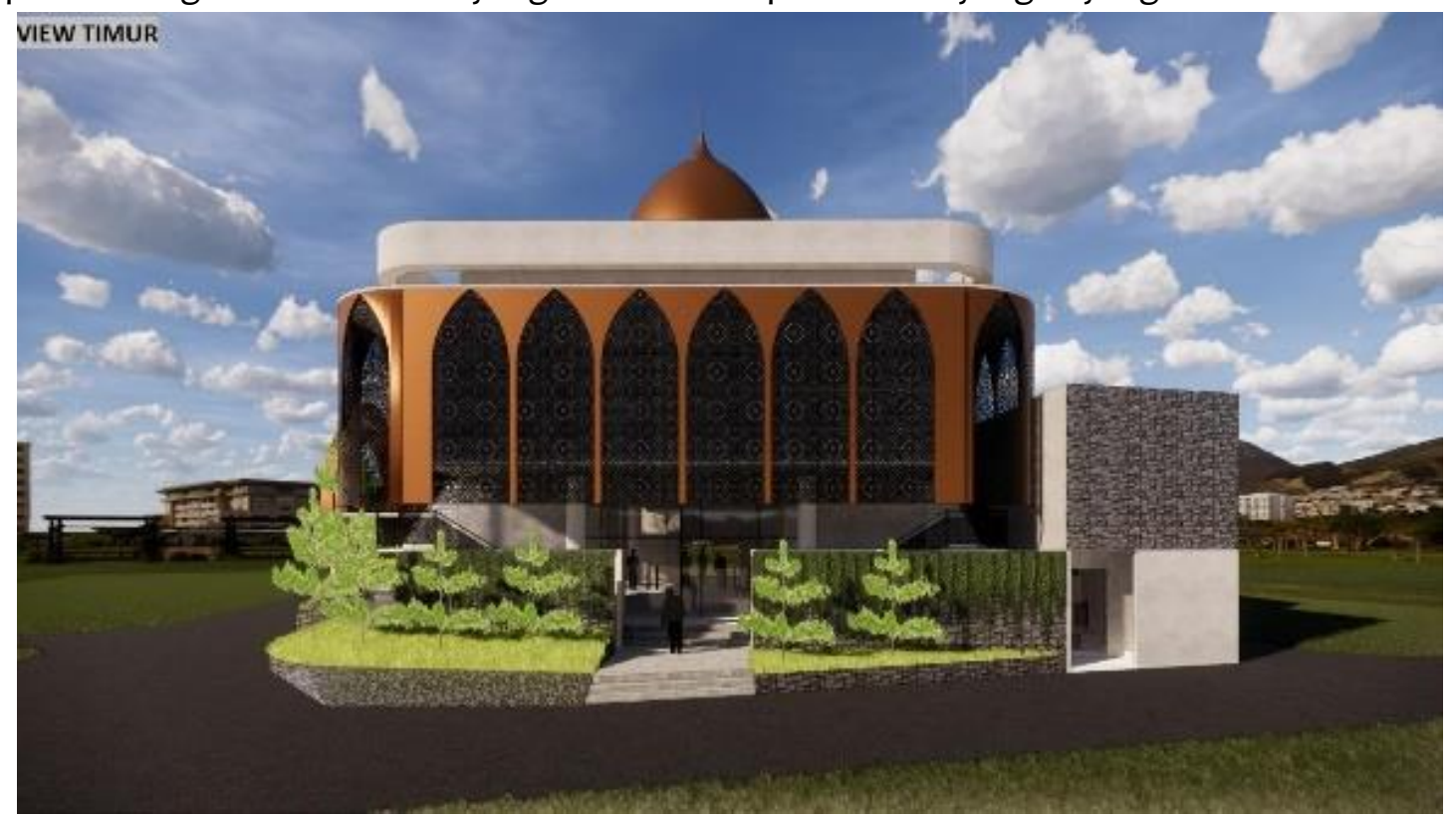

Gambar 11. Ornamen Islam dalam Fasade Masjid 


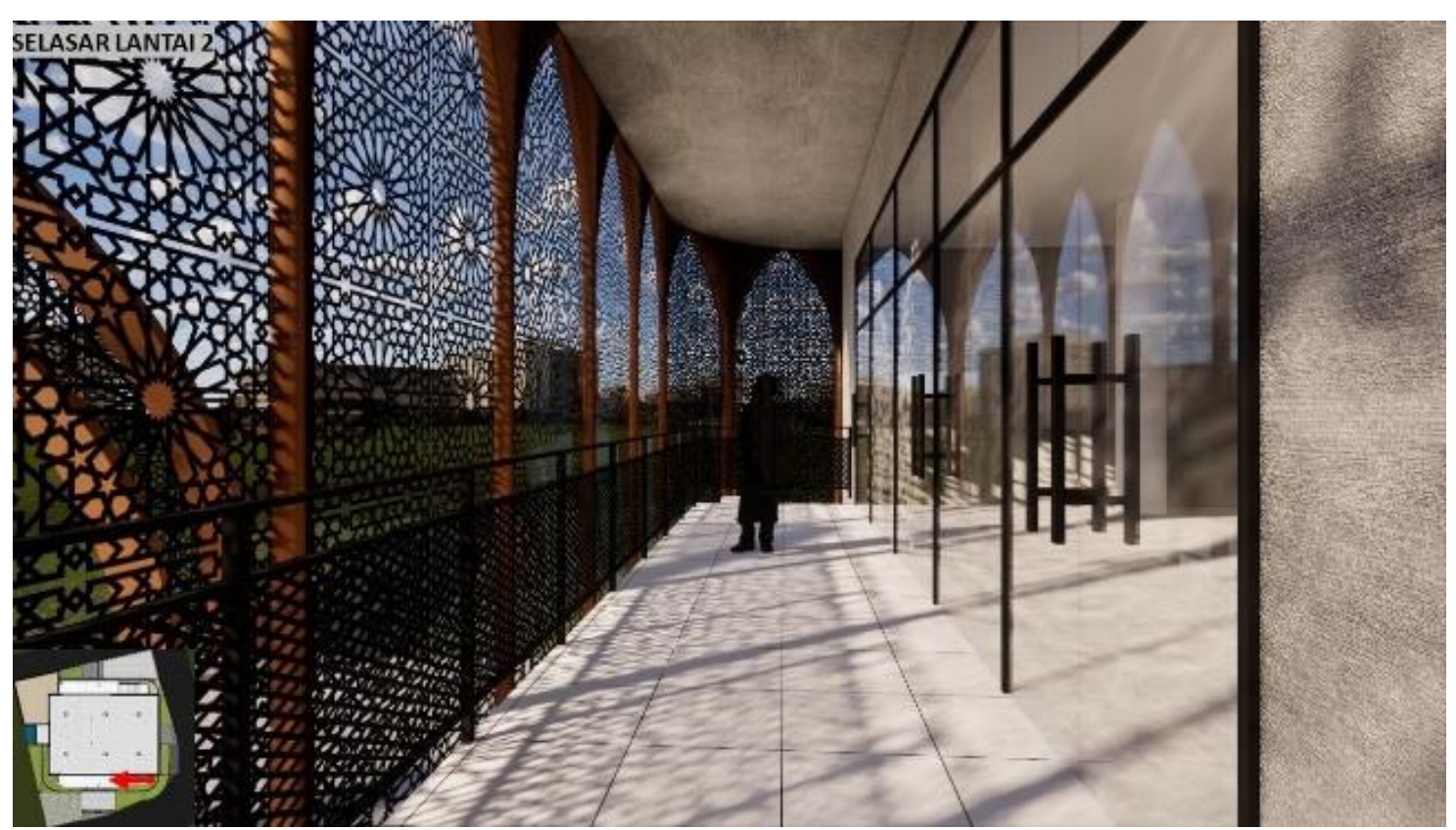

Gambar 12. Ornamen Islam sebagai Tabir Surya bagian dalam Masjid
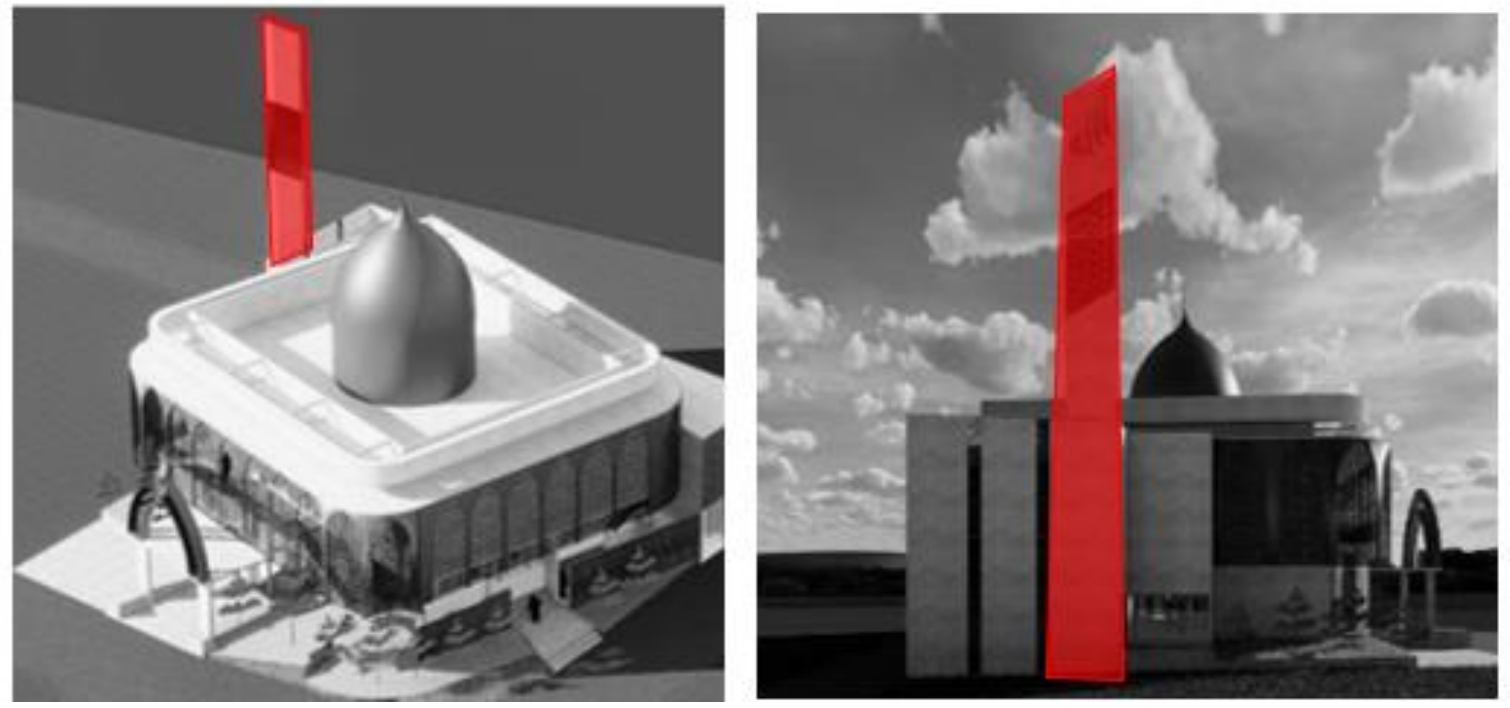

Gambar 13. Menara Masjid sebagai Penanda dari Kejauhan

Sebuah menara masjid yang menjulang anggun hadir sebagai penanda kehadiran masjid, sekaligus penanda bagi jamaah maupun pengunjung yang akan menuju masjid dari jarak yang cukup jauh.desain menara dibuat menyatu dengan bangunan penunjang berupa rental tower, ruang istirahat imam dan ruang dewan Keluarga Masjid untuk tetap memperlihatkan kesatuan. Bagian menjulang dari tower ini dibuat ramping dan ada bagian yang transparan sehingga terkesan ringan namun elegan. Fungsi bangunan penunjang lainnya adalah bangunan servis berupa gudang dua lantai. Pada lantai pertama diperuntukan untuk menyimpan peralatan yang memiliki volume besar atau berat seperti tenda masjid, bangku lipat, perangkat system pengeras suara, hingga alat pertukangan. Peletakan fungsi di ruang ini di lantai bawah dan akses menuju bangunan servis yang terpisah dari bangunan utama dimaksudkan untuk memudahkan untuk mobilisasi barang tanpa menggangu aktivitas beribadah di dalam masjidnya. Sedangkan di lantai dua terdapat fungsi gudang peralatan dan perlengkapan operasional masjid harian dan memiliki keterhubung dengan lantai dua masjid untuk 
kemudahan mengambil peralatan saat akan melaksanan kegiatan pengajian. Seperti halnya bagian ruang istirahat imam, bangunan Gudang ini dibuat terpisah namun seolah menempel dengan fungsi bangunan utama agar tetap terlihat selaras. Ketinggian bangunan gudang ini pun disesuaikan dengan kebutuhannya sehingga tidak membebani anggaran pembangunan seperti jika ketinggian antar lantainya mengikuti masjid.
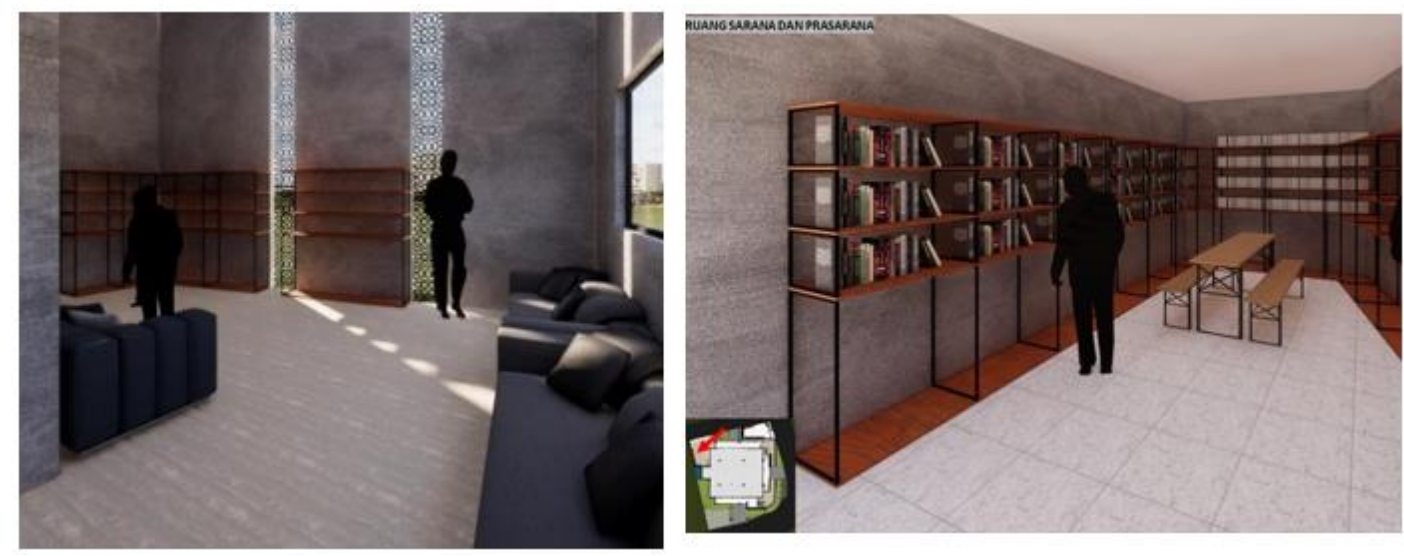

Gambar 14. Suasana di dalam ruang dkm dan Gudang perlengkapan

Untuk ruang dalam masjid, desain interior dibuat sederhana dan polos untuk meminimalisisr adanya gangguan fokus saat jamaah sedang shalat maupun melakukan pengajian. Desain bangunan juga hanya menekankan skala ruang yang dapat membuat rasa kecil bagi para jaaah yang sedang beribadah tanpa membuatnya secara berlebihan.
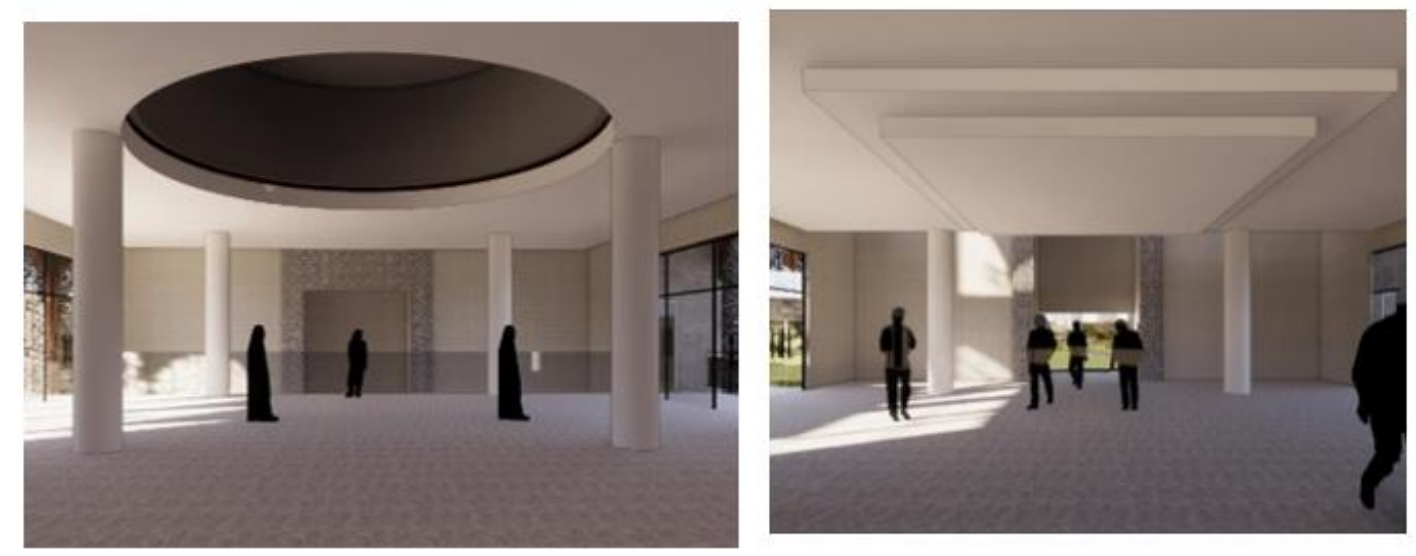

Gambar 15. Suasana di dalam Masjid

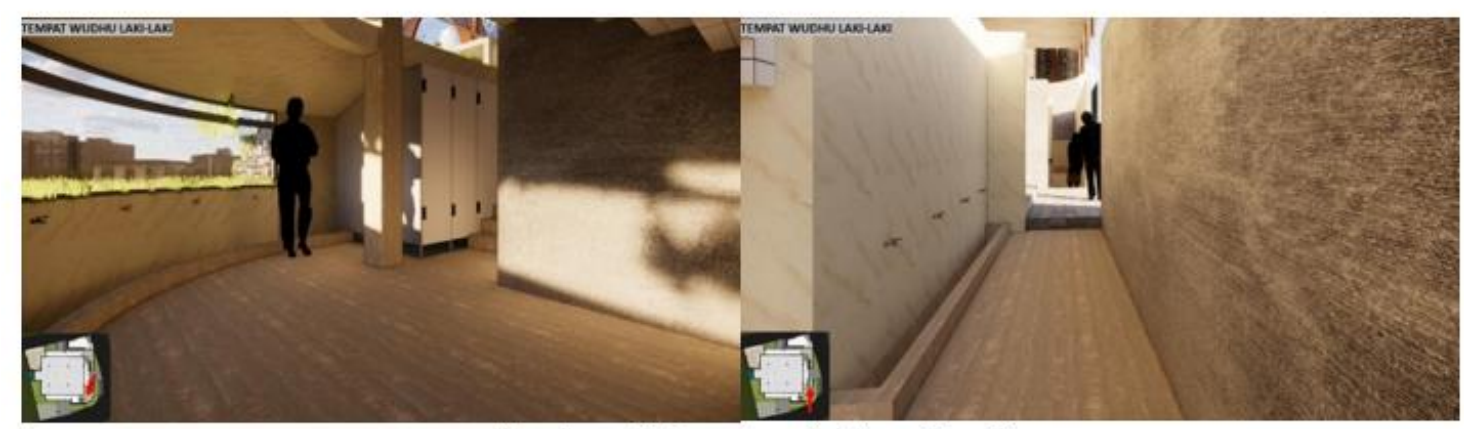

Gambar 16. Suasana di dalam Masjid 
Untuk interaksi antar lantai dan memaksimalkan hirarki shalat pada shaft pertama, bagian barat laut masjid yang menygarah ke mihrab diputus pada 2 shaft pertama dan dibentuklah void yang menjadi sarana inters vertical antar lantai saat shalat berjamaah. Layaknya umumnya masjid di bagian depan masjid terdapat kubah besar yang memberikan perasaan ruang yang gigantis saat berada dibawahnya. Fungsi penunjang lainnya adalah ruang wudhu dan toilet. Isu yang sering dihadapi pada fungsi ruang ini adalah lembab, gelap, pengap dan jorok. Stigma ini coba di balikan dengan menghadirkan fungsi ruang toilet yang walaupun berada di bawah tangga tetap bisa memaksimalkan cahaya matahari secara optimal dengan sirkulasi udara alami yang baik pula. Pemilihan material yang tahan lama serta berwarna cerah memberi kesan pada ruang yang bersih elegan namun tidak menghamburkan anggaran secara berlebihan. baik di dalam bangunan maupun di luar bangunan masjid ini didesain dengan banyak elemen kejutan ruang yang dikemas secara sederhana dan tetap merunduk, seperti mengingatkan kita begitu kecil dihadapan sang pencipta.

Setelah panjang lebar membahas mengenai desain tampilan bangunan, tahapan krusial lainnya dari desain masjid ini adalah skenario pembangunan. Bukan hanya masalah tahapan pembangunan berdasarkan anggaran, namun juga porsi keterlibatan tenaga ahli dalam proses pembangunan, melibatkan kontraktor atau pelaksana bangunan lokal, serta keterlibatan warga dan partisipasinya dalam membangun. Pertimbangan pertimbangan ini adalah kesepakatan tim pengabdi dan mitra guna membangun rasa memiliki yang besar dari seluruh warga puri harmoni 1 selaku pengguna bangunan masjid ini. Untuk menjembatani hal tersebut maka disepakati bahwah untuk pekerjaan struktur dilakukan oleh tenaga ahli yang sudah tersertifikasi dengan penganggaran yang telah disepakati bersama, sedangkan untuk tahapan finishing sebagian bisa dilimpahkan kepada pemborong lokal dan pengerajin dibidang terkait, sementara warga adalah pada tahapan finishing pembersihan, pengecatan bagian tertentu dan peletakan elemen dekoratif di dalam masjid. Untuk memungkinkan kondisi terbut maka dibutuhkan pemahaman mendalam dari desain masjid ini untuk setiap lapisan pengguna, sehingga kami selaku pengabdi menyediakan gambar perencanaan yang juga dapat dipahami oleh masyarakat awam dari segi teknis pembangunan dan material yang digunakannya.

\section{PENUTUP}

Dalam kegiatan abdimas seperti ini memang lebih mudah jika bisa melibatkan banyak pihak sehingga bisa menyerap aspirasi dari seluruh pihak yang akan menggunakan sarana bersama ini. Dalam proses desain masjid ini pihak mitra sangat membantu setiap proses dan membangun kerja sama yang baik demi terwujudnya tujuan dari kegiatan ini. Seperti pada saat proses FGD bersama warga, banyak perbedaan pandangan dan ada masa cukup berat dimana ada kesulitan menyamakan visi desain terutama karena masalah kebiasaan dan penganggaran biaya pembangunan. Selain itu terdapat keterbatasan ruang bertemu karena pandemic yang terkadang membuat perselisihan pandangan, namun dengan segala keterbatasan tersebut tidak mengurangi semangat warga untuk bisa mewujudkan desain masjid ini. Kegiatan desain ini berlangsung cukup intensif dan membahas secara keseluruhan permasalahan yang mungkin dihadapi mulai dari factor budaya dan kebiasaan, perbedaan tata cara beribadah sesuai dengan paham masing masing, tahapan pembangunan yang ideal dilakukan agar setiap anggaran dana yang dikeluarkan dalam setiap tahapnya bisa dimanfaatkan untuk pekerjaan yang efektif dan dapat diaplikasikan sesuai dengan visi desain dan gambar perencanaannhya. Pembagian porsi andil pembangunan pun disesuaikan mana yang membutuhkan ahli bangunan dan mana yang bisa dikerjakan bersama oleh warga untuk menjaga agar setiap langkah yang dilakukan bisa membangun rasa memiliki bagi warga Puri Harmoni 1. 


\section{DAFTAR PUSTAKA}

Almusaed, Amjad. 2011. Biophilic and Bioclimatic Architecture. London: Springer.

Aryanti. F.Y, Arum. K., Indah. Y. 2020. Perancangan Museum Bumi di Jakarta dengan Pendekatan Arsitektur Biofilik. Jakarta: prosiding Seminar Nasional Komunitas dan kota Berkelanjutan, vol 2 no 1. http://www.proceeding.unindra.ac.id/index.php/semnaskkbarsi/article/view/5041/992

Badri Yatim, Dr., MA. 2000. Sejarah Peradaban Islam. Jakarta: PT. Raja Grafindo Persada.

Browing, W.D., Ryan, C.O., Clancy, J.O. 2014. 14 Patterns of Biophilic Design. New York: Terrapin Bright Green, LL C. Johanson, Megan. 2019. https://www.terrapinbrightgreen.com/reports/14patterns/

Johansson, Megan. 2019. Biophilic Design and Wellness: Non-Rhythmic, Tehermal and Airflow, and Water Patterns. https://velacreative.com/journal/2019/1/29/biophilic-design-and-wellness-nonrhythmic-thermal-and-airflow-and-water-patterns.

Johansson, Megan. 2019. Biophilic Design and Wellness: Dynamic \& Diffuse Light and Connection With Nature Systems. https://velacreative.com/journal/2019/3/26/biophilic-design-and-wellnessdynamic-amp-diffuse-light-and-connection-with-natural-systems

https://www.terrapinbrightgreen.com/reports/14-patterns/ 